TR

U6 $2 \mathrm{~B} 9$

$192 \varnothing$

NMAA 


\section{First National}

\section{Exhibition of Pictorial Photography}

under direcrion of

THE BUFFALO CAMERA CLUB

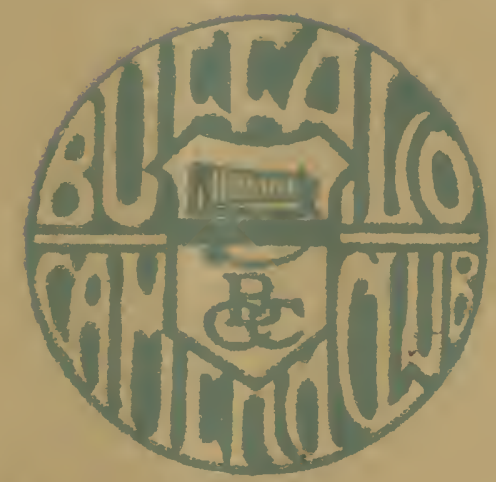

MAR 10 1920:

248218

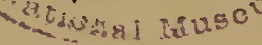

ALBKICYHT AKI GALLHRY

BCIFFALO, N Y.

February 24 to Manch 30

1920 




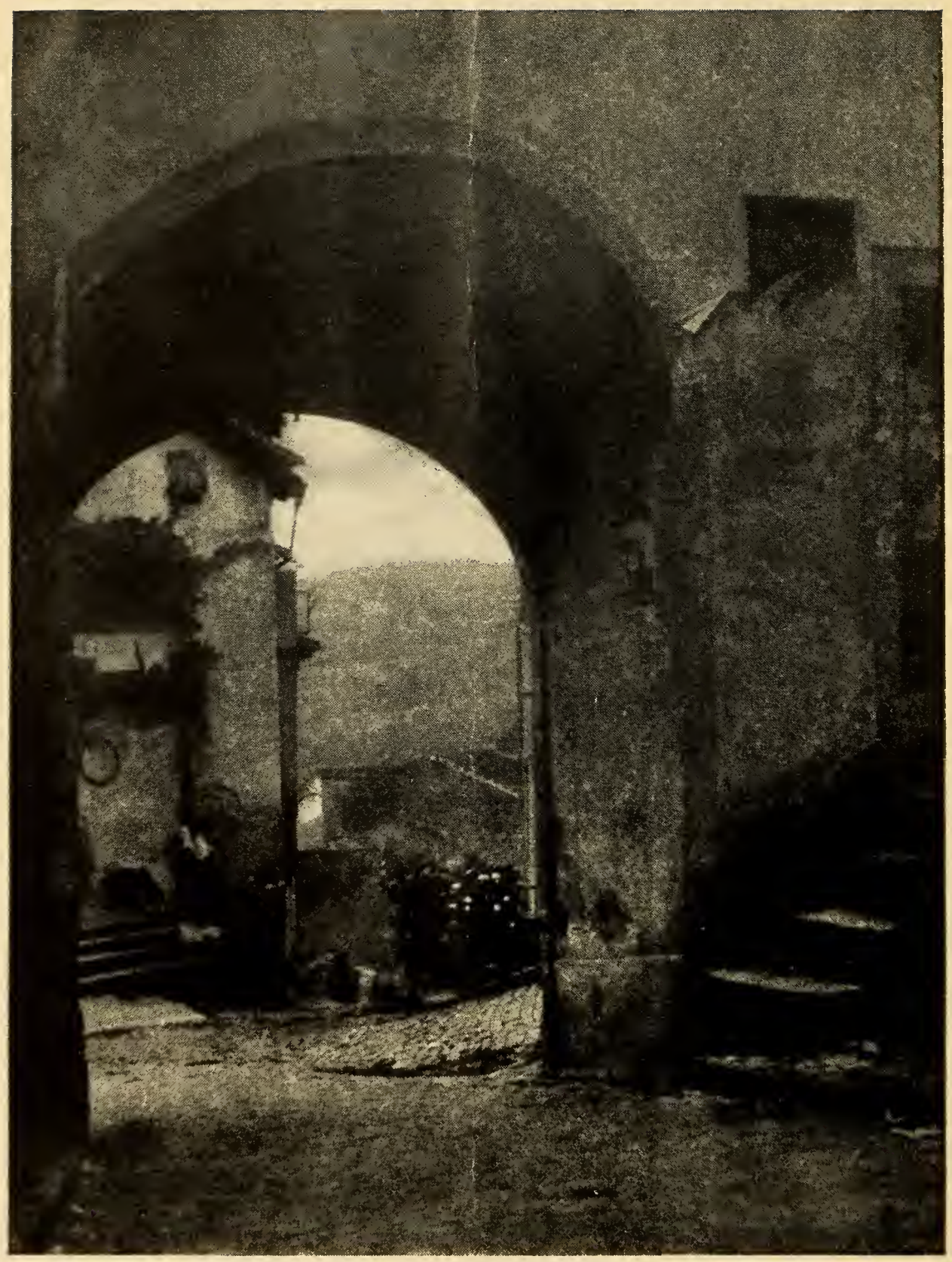

"CORDES, TARN"

A. D. Chaffee 


\section{First National}

\section{Exhibition of Pictorial Photography}

under direction of

\section{THE BUFFALO CAMERA CLUB}

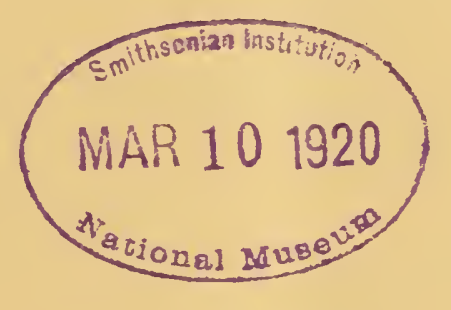

\section{ALBRIGHT ART GALLERY \\ BUFFALO, N. Y.}

February 24 to March 30 1920 


\title{
CATALOGUE OF EXHIBITION
}

\author{
FRED. R. ARCHER \\ Los Angeles, Cal.
}

1. From a Hillside

2. While the Flock Is Grazing

3. Youth

4. The Supplicant

HOWARD D. BEACH

Buffalo

5. Portrait of Master W.

6. Portrait of Miss W.

7. Portrait of Miss M.

8. Portrait of Master A.

DAVID W. BONNAR

\section{Buffalo}

9. A Glimpse of Buffalo River

10. Historical Building

\section{ALICE BOUGHTON}

New York

11. Mother and Child

12. A Dancer

13. Rosalind Fuller

14. Madame Yvette Guilbert

ANNE BRIGMAN

Oakland, Cal.

15. The Breeze

16. The Water-nixie

17. The Loreli

18. The Hamidryads 
JAMES H. BRODIE

Buffalo

19. Phantom
A. D. CHAFFEE
New York

20. Weissthurn, Rothenburg o. Tauber

21. Portland Wharves, Maine.

22. Tauber Valley

23. Cordes, Tarn

C. W. CHRISTIENSEN

Chicago

24. Cedars Sedate

25. A Dragoon of the Grand Canyon

26. A Sphinx at Night

27. In Reverent Mood

\section{FRANCIS W. COWELL Buffalo}

28. Water-gate, Moonlight

29. Storm

30. Light Canvas

31. Cover Design

J. J. DWYER

$$
\text { Buffalo }
$$

32. The Lift Bridge

33. The End of the Path

34. In a Cottage

\section{LOUIS FLECKENSTEIN}

Los Angeles, Cal.

35. Betallo Rubino

36. Miss Lucy S.

37. Marguerite Tew

38. The War Widow 


\section{FORMAN HANNA \\ Globe, Arizona}

39. Bake Ovens, Taos.

40. Old Church, Laguna

41. Storm, Grand Canyon

42. Santa Domingo Indians

$$
\begin{aligned}
& \text { W. A. HUDSON } \\
& \text { Los Angeles, Cal. }
\end{aligned}
$$

43. St. Mary's Abby, York

44. The Joe Hunter

45. Lombardy Poplars

46. The Shambles, York

ARTHUR F. KALES

Los Angeles, Cal.

47. Pierrot Forlorn

48. Nude in High Key

49. Arrangement Japanesque

50. Springtime

\section{G. EDWIN KELLER}

Buffalo, N. Y.

51. Landscape

T. W. KILMER

$$
\text { New York }
$$

52. Major G. M. Hammond

53. Captain McWilliams

54. Colonel W. S. Conrow

55. A. Jacobi, M. D.

\section{FRANCIS ORVILLE LIBBY}

Portland, Maine

56. Beyond

57. Crepuscule

58. "The Heavens Declare the Glory of God"

59. Mount Adams of the Northern Peaks 


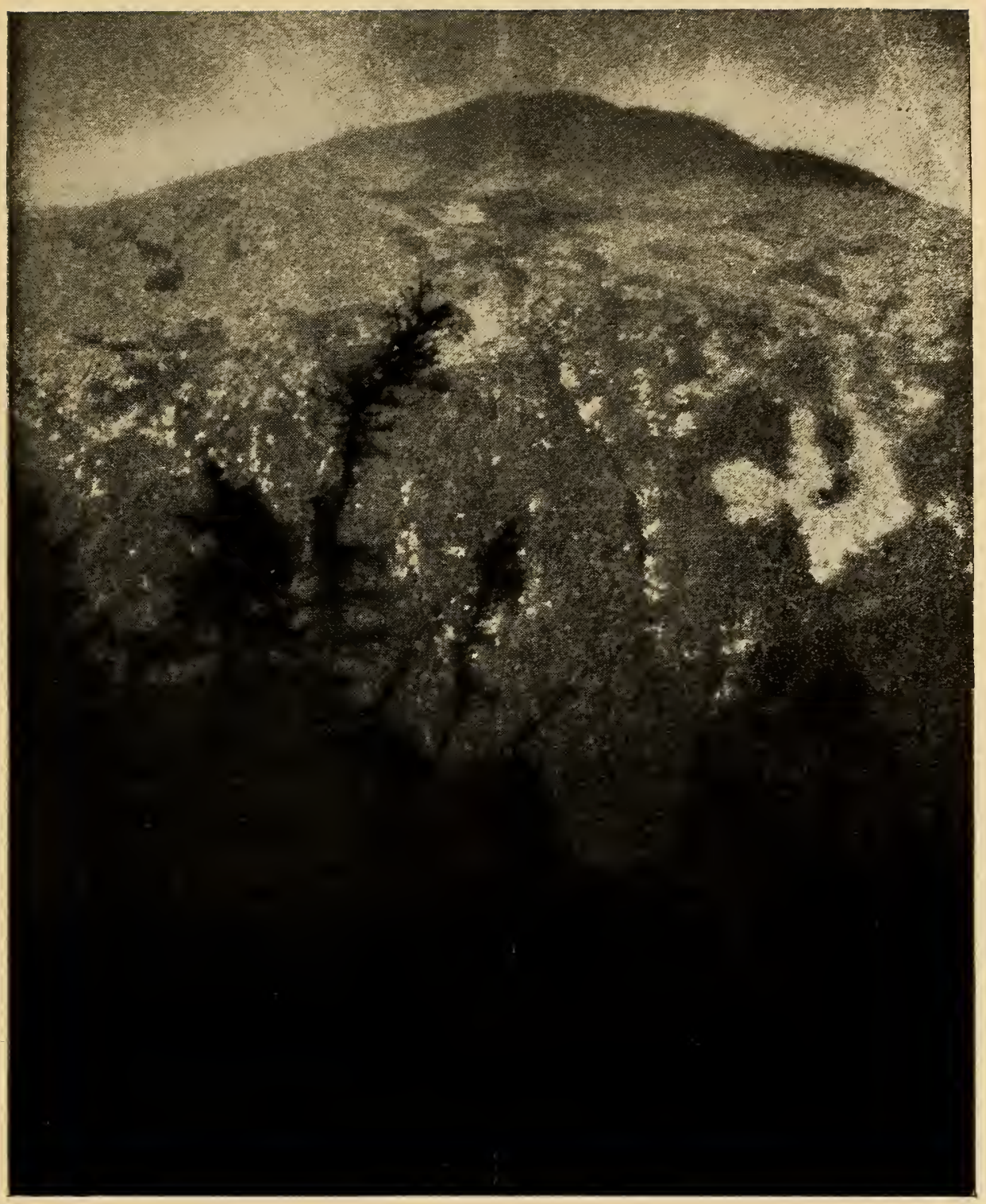

"MOUNT ADAMS OF THE NORTHERN PEAKS"

Francis Orville Libby 
RUPERT S. LOVEJOY

Portland, Maine

60. Misty Moon

61. A Summer Symphony

62. Prelude of Night

63. Surf

\section{MARGRETHE MATHER}

Los Angeles, Cal.

64. Player on the Yit-kin

65. Edward Weston

66. Charles Gerard

67. Eugenia

ROBERT R. McGEORGE

Buffalo

68. Miss $\mathrm{H}$.

69. "A Gob"

CLAUDE L. MOORE

Buffalo

70. Close Inshore

71. When Evening Comes

72. Dawn

73. The Eyes of the Harbor

\section{REMICK NEESON}

Baltimore

74. Kitchen Things

75. Blue China

76. The Black Sheep

77. Sirens 


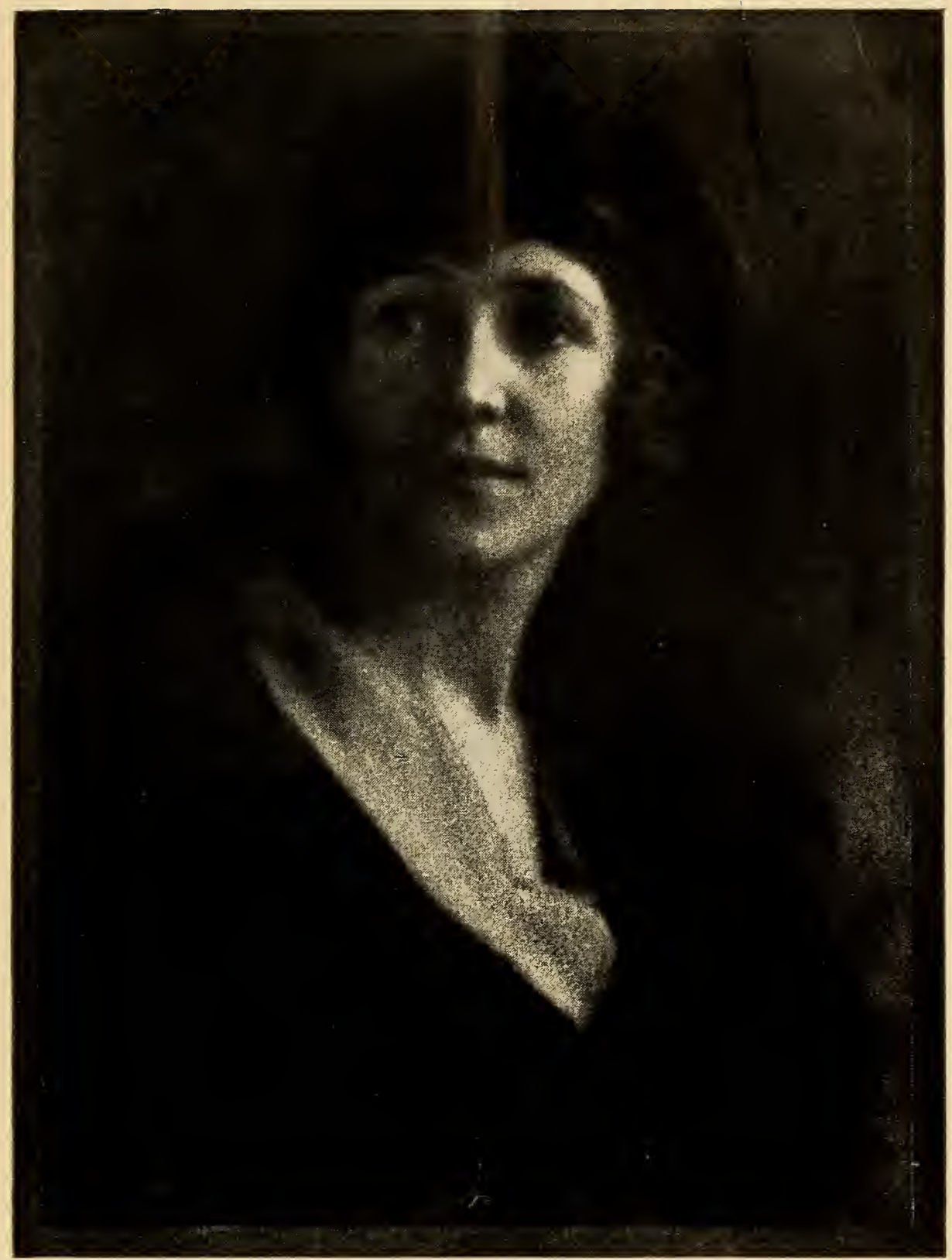

"MISS LUCY S."

Louis Fleckenstein 


\section{CHARLES L. PECK \\ Buffalo}

78. Boy With Kite

79. A Harbor Vista

\section{A. PIERMAN \\ Buffalo}

80. The Lonely River

81. The Ohio

\section{WILBUR H. PORTERFIELD}

Buffalo

82. Toward Evening

83. Twilight's Mystery

84. Vision Dorésque

\section{O. C. REITER}

\section{Pittsburgh}

85. Danse des Arbres

86. The Husbandman

DR. D. J. RUZICKA

New York

87. The Stygian Grove

88. The Evening Paper

89. Carmel Bay, Cal.

90. The Sunlit Urn

\section{HENRY W. SCHONEWOLF}

Buffalo

91. A Summer Morning at Point of Woods

92. New York: An Early Morning Impression

93. Alone 


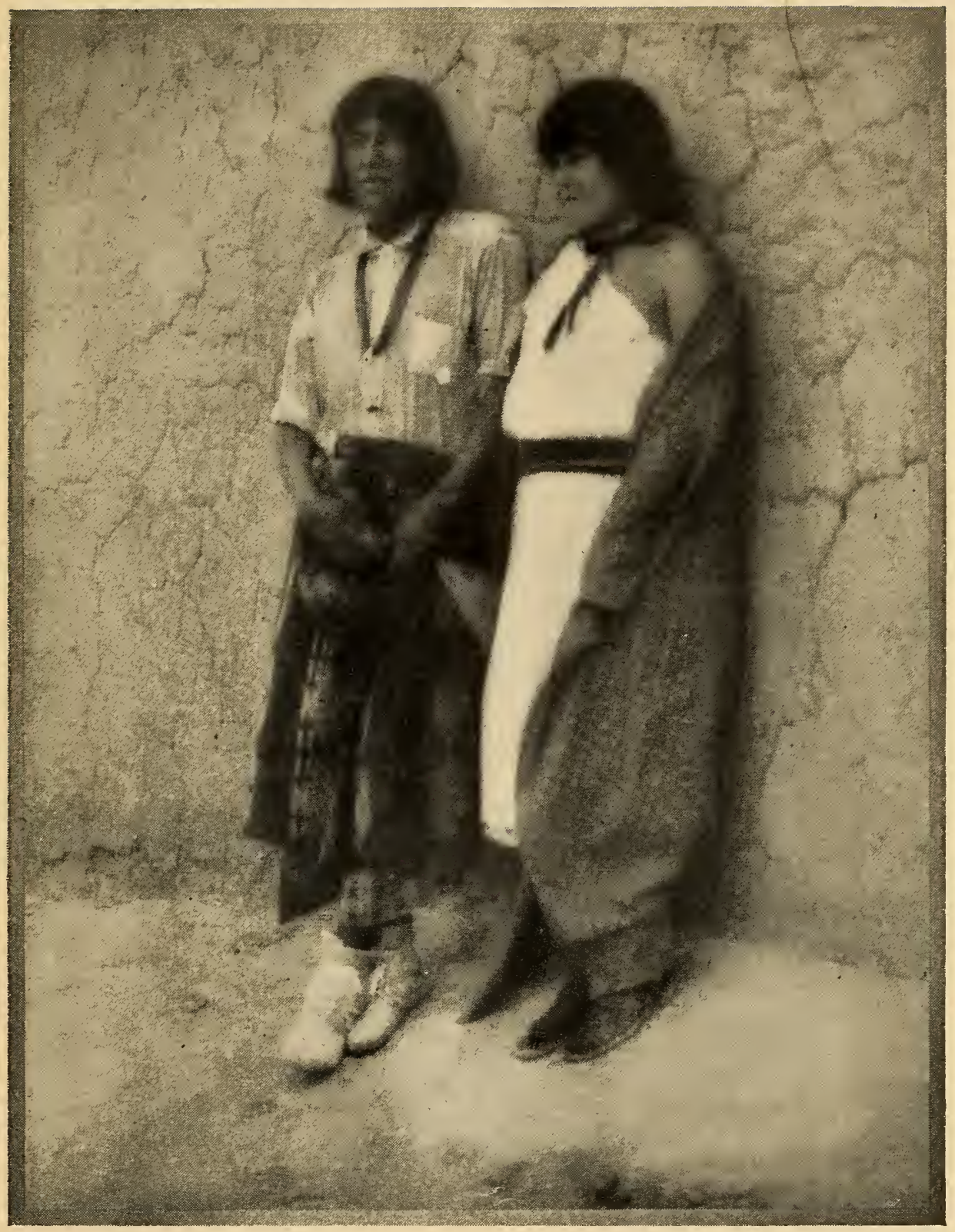

"SANTA DOMINGO INDIANS"

Forman Hanna 


\section{WILLIAM GORDON SHIELDS \\ New York}

94. Heart of the Woods

95. A Gatherer of Flowers

96. Cherry Hill, New York

97. Corinthian Columns

\section{FRANCIS J. SIPPRELL Buffalo}

98. Portrait

\section{ALBERT SNYDER \\ Utica, N. Y.}

99. Approaching Storm

100. October Twilight

101. Late Afternoon

\section{HUGH THOMAS \\ Buffalo}

102. A Sussex Worthy

103. From the Garden of Khama

104. Mowing

\section{JULIA WALBRIDGE}

$$
\text { Buffalo }
$$

105. "My Betsy"

106. "Charlote"

107. "Three Sisters"

108. "The Chinese Robe"

$$
\begin{gathered}
\text { EDWARD H. WESTON } \\
\text { Los Angeles }
\end{gathered}
$$

109. Margrethe and Plum Blossoms

110. Bathing Pool

111. Epilogue (Margrethe Mather)

112. Torso 


$$
\text { . }
$$




\section{A New Industry For Buffalo}

The Buffalo Gravure Co. is the only plant in Buffalo, or within a radius of two hundred miles, equipped to produce Rotogravure, the latest and most beautiful type of printing and yet the most economical process.

We solicit all forms of commercial printing, catalogues, inserts, broadsides, etc.

Rotogravure gives to your pictures a distinctive, exclusive richness, a refinement that will add to your prestige and give greater impetus to your sales.

A thoroughly equipped plant with proficient personale is at your command. We invite inspection of our enterprise, where you may see the beautiful effects we can produce.

Newspaper supplements.

BUfFALO GRAVURE CO., INC. 85 PEARL STREET . . . BUFFALO, N. Y. 


\section{J. F. ADAMS 459 WASHINGTON ST.}

Kodaks, Graflex, View and Portrait Cameras.

Developing, Printing and Enlarging.

Balopticons for the

Projection of Lantern Slides and Post Cards.

Graphoscope, a safe, Standard Size Motion Picture

Projector. 
BUFFALO EVENING NEWS THE PAPER THAT GOES HOME 


\section{Better Photography}

This beautiful symbol stands for better photography - with less effort, with less failure, with less investment of time.

For this symbol typifies the years of striving and learning concentrated in the Bausch $\&$ Lomb institution.

Tessar Anastigmat Lenses are the essence of the finest in lens manufacture, for they embody all the optical knowledgethe result of years of research-for which this organization is famous.

Every photographer-amateur or professional, who exposes through Tessars, works with the finest tools that can be made.

\section{Bausch $\mathcal{E}$ lomb Optical (0. NEW YORK WASHINGTON CHICAGO ROCHESTER, N. Y. \\ SAN FRANCISCO \\ LONDON}

Leading American Makers of Microscopes, Projection Lanterns (Balopticons), Photographic and Ophthalmic Lenses, Stereo-Prism Binoculars, Range Finders, Gun Sights, Searchlight Mirrors and other High-Grade Optical Products. 


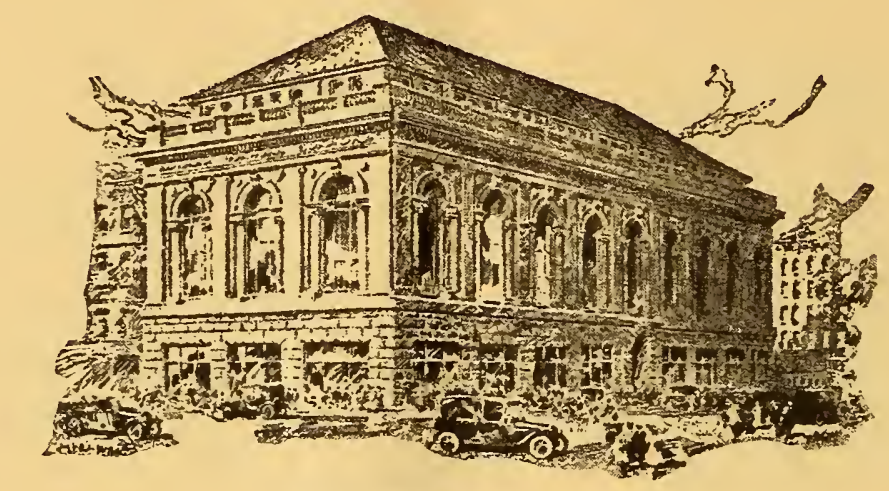

New Building (when completed)

\section{BANK OF BUFFALO}

Head Office:

Main and North Division Streets

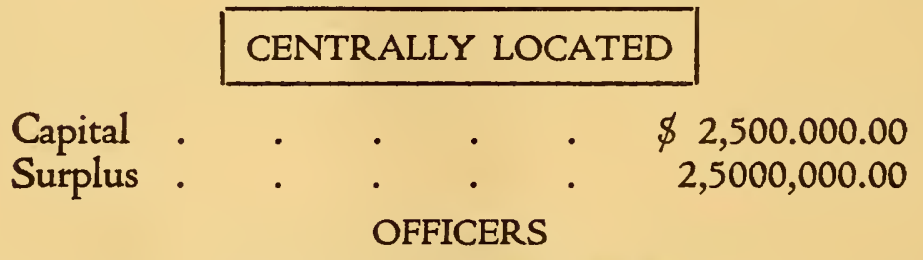

Elliott C. McDougal, President

Robert K. Root, . Vice President Charles D. Appleby, Assistant Cashier Ralph Croy, . . Vice President August J. Duerr, Assistant Cashier Samuel M. Johnson, . Cashier Arthur J. Hall, . Assistant Cashier Louis C. Olden, Assistant Cashier T. B. F. Olsen, Manager Bond Dept.

\section{CITY TRUST COMPANY BRANCH}

\section{Erie County Bank Building}

Frank M. Hickok, Secretary and Trust Officer

James T. Gunning, Assistant Secretary Hugh McRae, Assistant Secretary William G. Richard, Assistant Secretary

\section{MARKET BRANCH}

Main and Chippewa Streets

Leslie P. McDougal, Assistant Cashier J. Alfred Edwards, Assistant Cashier Walter E. Duerr, Assistant Cashier

WE INVITE YOUR ACCOUNT 


\section{The Master Camera}

All the knowledge and skill of sixty years' camera making have been concentrated in the Ansco V.P Speedex No. 3-a superb pocket companion for anyone who appreciares that which is the best of its kind.

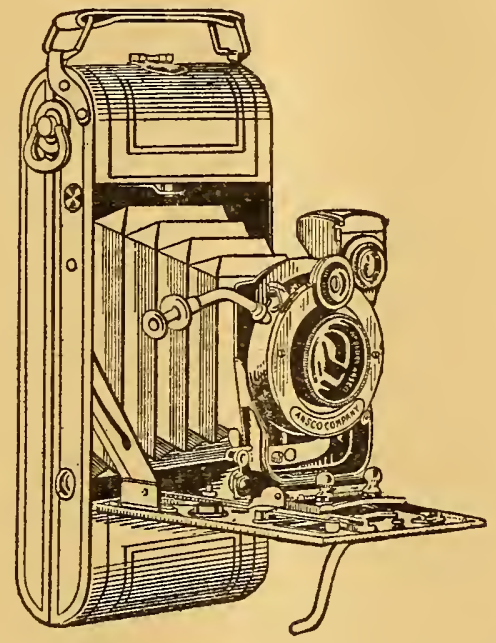

With the finest of fine lenses and shutter equipments, it produces sharp, clear $2 \frac{1}{4} \times 3 \frac{1}{4}$ inch pictures in rain, sunshine or shadow.

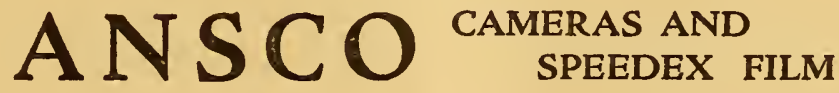

The user of the V-P Speedex No. 3 can quickly change the speed, the lens opening and the focus without losing sight of the image in the "finder" - an exclusive Ansco feature which makes picture-taking easier and more certain.

The Ansco V-P Speedex No. 3 is extremely simple in operation, exceptionally beautiful in appearance and extraordinarily efficient.

Write for specimen picture on Cyko Paper. Then ask the Ansco Dealer for a demonstration.

\section{ANSCO COMPANY}

BINGHAMTON, NEW YORK 
IF you ask at the store for a Kodak camera, or Kodak film, or other Kodak goods and are handed something not of our manufacture, you are not getting what you specified, which is obviously unfair both to you and to us.

"Kodak" is our registered and common law trademark* and cannot be rightly applied except to goods of our manufacture.

* TRADEMARK: Any symbol, mark, name or other characteristic or arbitrary indication secured to the user by a legal registration, adopted and used, as by a manufacturer or merchant to designate the goods he manufactures or sells and to distinguish them from the goods of competitors.

STANDARD DICTIONARY.

If it isn't an Eastman, it isn't a Kodak

\section{EASTMAN KODAK COMPANY ROCHESTER, N. Y.}

At your dealer's 
. 


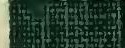

